\title{
Sosyal Medya ve Şiddet: Ekşi Sözlük'te Çinli Algısı
}

\author{
ÇAĞLA PINAR TUNÇER \\ caglapinartuncer@hakkari.edu.tr \\ ORCID ID: 0000-0001-6114-6909
}

\begin{abstract}
Öz: Teknolojik gelişmelerle hızı, etkisi ve yayılımı artan medya, kurduğu "gerçeklik"te şiddeti ve egemen değerleri öğretmekte, meşrulaştırmakta, yeniden üreterek normalleştirmektedir. Medyada nefret söylemiyle ifadesini bulan sembolik bir şiddet kullanılmaktadır. Bu çalışmada, yeni medyanın popüler platformu Ekşi Sözlük'te pandemiyle birlikte Çin/Çinliler hakkında üretilen söylemler incelenmiştir. Ekşi Sözlük yazarlarının girdileri, içerik ve eleştirel söylem analiziyle incelenerek, Çin/Çinlilerle ilgili hangi temaların kullanıldiğı, nasıl ötekileştirildikleri ve tanımlandıkları ortaya konulmuştur. Yapılan değerlendirmede nefret söylemi kullanıldığı, olumsuz stereotipler ve ön yargıların dolaşımda olduğu, komplo teorileri ve milliyetçi-dini referanslarla beslenen bir ikna retoriğine başvurulduğu görülmüş, dehumanizasyon ve intrahümanizasyona rastlanmıştır. Şiddete dönüşme potansiyeli taşıdığından kolayca üretilen yeni medya içeriklerinin nefret söyleminden arındırılması gerekmektedir.
\end{abstract}

Anahtar kelimeler: Yeni medya, Şiddet, Nefret söylemi, Pandemi, Çinliler.

\section{Giriş}

Dar anlamıyla fiziksel zor olarak düşünülen şiddet olgusu ekonomik, cinsel, sembolik, siyasal, psikolojik şiddet gibi çok farklı biçimleriyle karşımıza çıkmaktadır. Medya söz konusu olduğundaysa şiddetin görünmeyen biçimleriyle; sembolik şiddet ve psikolojik şiddet unsurlarıyla karşılaşılmaktadır.

İletişim teknolojilerindeki gelişmeler mesafeleri ortadan kaldırarak dünyanın her noktasından anlık haberdar olma imkânı verirken, şiddet içerikli yayın ve söylemlerin yayılmasını da sağlayarak şiddeti olağanlaştırmıştır. Yeni medya olarak nitelendirilen, özellikle sosyal medya haliyle gündemimizde olan Web 2.0, geleneksel medyanın aksine kullanıcıları baz alması ve sunduğu özgür ortamla yaygınlaşmıştır. Öte yandan denetimsiz bir alan olması nefret söylemlerine zemin yaratmaktadır. Dilsel bir şiddet türü olarak nefret söylemi, her an nefret suçuna dönüşme potansiyeli taşımakta, toplumsal belleği yansıtmakta ve ideolojik söylemin yeniden üretimine geleneksel medyadan çok daha güçlü bir biçimde katkı sunmaktadır.

\footnotetext{
* Öğr. Gör., Hakkari Üniversitesi, İktisadi ve İdari Bilimler Fakültesi.
} 
Türkiye'de oldukça popüler bir uygulama olan Ekşi Sözlük, maalesef nefret söyleminin üretildiği platformlardan biri haline gelebilmektedir. Katılımcıların fikirlerini özgürce dile getirdiği sözlük ortamı, denetimsizlik ve ifade özgürlüğüyle karıștırılması dolayısıyla nefret söylemini normalleștirmektedir.

$\mathrm{Bu}$ çalışmada etkileri hala süren Corona/Covid-19 pandemisiyle Çin/Çinliler hakkında yaygınlaşan nefret söyleminin Ekşi Sözlük’teki yansıması değerlendirilecektir. Dünyada ve Türkiye'de Çin/Çinlilere tepkilerin yükseldiği, geleneksel ve sosyal medyada nefret söyleminin arttığ 1 görülmektedir. Karantina uygulamaları kaldırılıp hayat normale döndügünde nefret suçu olarak karşımıza çıkma potansiyeli bulunması, nefret söylemi ve nefret suçlarına dair gerekli yasal düzenlemelerin yapılması ve toplumun bilinçlendirilmesinin gerekliliğini ortaya koymaktadır.

\section{Medya ve Şiddet}

Günümüzde televizyonun yanı sıra bilgisayar oyunları, internet ve sosyal medya kanalıyla da şiddet yaygınlaştırılmaktadır. Özellikle geniş kitlelere hitap eden televizyon söz konusu olduğunda görsel şiddet içeren yayınlarla şiddetin "öğretilmesi”" söz konusudur. ${ }^{1}$ Geleneksel medya olarak adlandırılan televizyon ve yazılı basının her gün milyonlarca kişi tarafından takip edilen gazeteler, dergiler, diziler, filmler, haber görselleri, spor programları, çizgi filmler hatta mizah programlarıyla şiddetin öğrenilmesine, içselleştirilmesine ve şiddete karşı duyarsızlaşmaya neden olduğu dile getirilmektedir. Uysal, sadece televizyon izleyerek bile gerçek hayatta karşılaşabileceğimizden çok daha fazla şiddete tanık olduğumuza dikkat çekmektedir. ${ }^{2}$ Birey, günlük hayat akışının beraberinde medya içerikleriyle de yoğun bir şiddete maruz kalmaktadır.

Medya bilgi verirken sunduğu imgelerle dünyaya dair algımızı, dolayısıyla davranışlarımızı belirleme gücü taşımaktadır. Çocuklar başta olmak üzere yetişkin bireyler de şiddet içeriklerinden olumsuz etkilenmekte, söz konusu yayınların şiddeti öğretici ve saldırganlığı teşvik edici etkisinden kaçamamaktadır. ${ }^{3}$ Bu bakımdan medyanın etki gücü toplumsal şiddetin artmasında önemli rol oynamaktadır. Milyonlarca kişiye ulaşabilen medya toplumsal zihniyeti dönüştürmektedir. Medya aracılığıyla şiddetin her yerdeliğinin sağlanması; şiddeti fark edilemez bir hale gelerek olağanlaştırmakta, daha önemlisi bir "çözüm" olarak sunarak normalleştirmektedir. ${ }^{4}$ Herkesin kendi adaletini kendince sağladığı ve güçlünün kazandığı bir dünya tipolojisi çizilmektedir. Toplumsal yapının dayandığı diyalog ve hukuksal süreçleri etkisiz ya da yok sayan bu söylemin sonuçlarıysa aşikârdır. Bu bağlamda çağımızın "belirsizlik ve korku” kültürünü yaygınlaştıran içerikleriyle medya, "güvenli” bir yaşam için gerekli araç olarak şiddeti meşrulaştırmaktadır. ${ }^{5}$ Sürekli şiddete tanık olmanın bilinçaltında

1 Yaşar Zorlu, "Medyadaki Şiddet ve Etkileri”, Humanities Sciences (NWSAHS), 11/1 (2016): 13-32.

2 Meral Uysal, "Medya ve Şiddet”, Bir Toplumsal Sorun Olarak Şiddet, Ankara: Eğitim-Sen Yayınları, 2006.

3 Refia Palabıyıkoğlu, "Medya ve Şiddet”, AÜ. Kriz Dergisi, 5/2 (1997), s.124.

4 Zorlu,"Medyadaki Şiddet”.

5 David Trend, Medyada Şiddet Efsanesi-Eleştirel Bir Giriş, çev., Gül Bostancı, İstanbul: Yapı Kredi Yayınları, 2008, s.80-84. 
yarattığı olumsuz etkiye dikkat çeken Uysal, ${ }^{6}$ sanal gerçekliğin içinde kaybolan bireylerin toplumsal sorunlara ilgisini kaybederek duyarsızlaştığını vurgulamaktadır. Çizilen karamsar tablonun yarattığı çaresizliğin ${ }^{7}$ bireylerin dünyayı değiştirme iradesini de köreltebileceği söylenebilir; zira "güçlü olan kazanır".

Medya iletilerinde şiddetin tamamlayıcı unsur olarak kullanılması, şiddetin araç haline geldiğinin göstergesidir. ${ }^{8}$ Özellikle gazetelerde ve haber programlarında şiddet görüntülerine sıkça yer verilerek izleyicinin dikkati çekilmeye çalışılmakta, "gerçeklik etkisi" arttırılmak istenmektedir. Bu ise medyadaki şiddetin iktisadi boyutuna işaret eder: kapitalist piyasadaki liderlik mücadelesinde medya şirketlerinin kâr marjlarını arttırma eğilimi şiddetin araçsallaştırılmasının nedenlerindendir. ${ }^{9}$ Her yaştan izleyici üzerinde etkili bir araç olarak şiddetin yaratacağı getirinin medya patronlarının gözünden kaçması imkânsızdır. Medya, etik ve toplumsal kaygılardan ziyade ticari kaygılarına öncelik vermektedir. Dijital efektler, ses efektleri, müzik gibi araçlarla şiddetin "estetize" sunumu reytingleri, tirajları arttırmakta, şiddeti cazip-eğlenceli hale getirmekte, böylelikle olağanlaştırmaktadır. ${ }^{10}$ Postman $^{11}$ televizyonda şiddet görüntüleri dâhil her şeyin eğlence çerçevesinde sunulduğunu, eğlencenin bir üst-ideoloji olarak işlev gördügünü vurgular. Benzer bir nitelik mizahi sunumda da izlenebilir; mizah şiddetin öğrenilmesini kolaylaştırmakta, şiddet karşısında duyarsızlaşmayı arttırmaktadır. ${ }^{12} \mathrm{Bu}$ bağlamda bir şiddet pornografisinden söz edilebilir, zira şiddet yarattığı şokla artık zevk vermektedir. İzleyicinin gözünde normalleşen şiddetin bir süre sonra medyanın arz-talep dengesine de etki etmesi kaçınılmazdır, zira şiddet bir döngü yaratmaktadır.

Bu çerçevede medyanın belirli bir dünya görüşünü, egemen değerleri aşılayarak gerçeklik algısını dönüştürdügü ve bambaşka bir dünya tasviri sunduğu "Ekme" kuramiyla ortaya konulmuştur. ${ }^{13}$ Medya böylelikle var olan düzeni, tutum ve davranışları güçlendirmekte, statükoya olan inancı pekiştirmektedir. Şiddet bağlamında değerlendirildiğindeyse, medyanın şiddeti toplumsal bir denetim aracı olarak kullandığını öne süren yaklaşımlardan "yetiştirme kuramı" televizyondaki şiddet içerikleriyle verilen mesajların anlamına ve yaratılan korku-güvensizlik havasının iktidar otoritesi lehine nasıl işlediğine odaklanmıştır. ${ }^{14}$ Bu noktada medyanın ideolojik etkisini dile getiren Marksist yaklaşımlara değinmek gerekir. Frankfurt Okulu kitle kültürü bağlamında medyanın kapitalizmin tüketim kültürünü yaygınlaştırırken kitleleri pasif tüketicilere dönüştürdügünü vurgulamıştır. Gramsci hegemonya teorisiyle rızanın oluşumunda kültürel alanın egemenliğinin önemine ve bu noktada medyanın rolüne

6 Uysal, "Medya ve Şiddet”, s.124-125.

7 Palabıyıkoğlu, "Medya ve Şiddet”, s.124.

8 Palabiyıkoğlu, "Medya ve Şiddet”, s.123.

9 Ömer Özer, "Medyada Şiddet Kullanımı: Şiddet Ekonomisi, Medyanın İdeolojik Şiddeti ve Yetiştirme Kuramı Açısından Bir Değerlendirme”, Marmara İletişim Dergisi, 27 (2017), s.5-7.

10 Trend, Medyada Şiddet, s.15-16, 78, 157; Uysal, “Medya ve Şiddet”, s.121.

11 Neil Postman, Televizyon: Öldüren Eğlence, çev., Osman Akınhay, İstanbul: Ayrıntı Yayınları, 2016, s.102.

12 Zorlu, "Medyadaki Şiddet, s.6.

13 Levent Yaylagül, Kitle İletişim Kuramları-Egemen ve Eleştirel Yaklaşımlar, Ankara: Dipnot Yayınları, 2017, s.73-76.

14 Özer, “Medyada Şiddet”, s.15. 
dikkat çekmiştir. Althusser de medyanın devletin ideolojik aygıtları içinde başat bir konumda olduğunu dile getirerek rıza üretiminin önemini vurgulamıştır. Kültürel Çalışmalardan Hall, toplumsal denetimin kurulması ve sürdürülmesindeki rolüne işaret ederek, medyanın dilsel pratiklerle üretilen belirli gerçeklik tanımlarını temsil ettiğini, gerçekliği yansıtmaktan ziyade belirli bir gerçeklik kurduğunu vurgulamaktadır. Medya, belirli anlam alanları oluşturarak toplumsal yaşamı yönlendirir; rıza ve meşruluğu inşa eder. Seçilmiş anlamları meşrulaştırırken farklı anlamları marjinalleştirir. Dolayısıyla ideolojik bir iktidar biçiminin aygıtı olarak medyanın işlevi, her sınıf ve grubu tanımlayan, toplumun bir bütün olarak tasavvurunu mümkün kılan toplumsal bilgi/imgeleri inşa etmektir. ${ }^{15}$

Van Dijk’a göre günümüzde bilgi ve kanaatleri belirleyerek söylemle "zihinsel denetim” sağlayan bir iktidar mevcuttur. Dolayısıyla simgesel seçkinlerle söylemlerin denetlenerek yeniden üretilmesi şarttır. Kitle medyasının denetimi bu yüzden çok önemlidir. Simgesel seçkinler gündemi, tutumları, kanaatleri belirleyerek toplumsal bilişi şekillendirir, güçlü gruplar lehine işleyen böylesi bir iktidar, ideolojiktir. ${ }^{16}$

Daha da önemlisi medya, toplumsal düzeni şiddet bağlamında tasvir etmektedir. ${ }^{17}$ Medya temsilleri ideolojik güç ilişkilerinden ayrı düşünülemez, dolayısıyla toplumsal hiyerarşiyi yansıtırken yeniden de üretir. Toplumsal bilinci belirleme gücüyle medya, toplumsal denetimin uygulanmasını sağlayan ideolojik araç olarak farklı kimlikleri ötekileştiren söylemsel bir şiddet üretmekte, şiddeti beslemektedir. Cinsiyetçi ve ırkçı temsilleriyle, cinsel şiddet içeren, azınlıkları ve farklı kimliğe sahip bireyleri kötü ötekiler olarak sunan klişeler de kullanan medya, yapısal olarak biz/öteki ayrımına dayanan ulusal kimliklerin yeniden üretilmesinde hayati rol oynar. Biz/ Ötekilere dair stereotipleri yeniden üreten ve pekişmesini sağlayan medya, toplumsal belleği ve bilinci düzenleyerek ötekilere karşı şiddeti meşrulaştırır. ${ }^{18}$ Van Dijk da aile, okul-eğitim, kültür-sanat gibi araçlarla birlikte etnik farkların olumsuz temsiliyle ırkçılığın yeniden üretiminde medyanın rolüne dikkat çekmektedir. Tipkı dinsel kurumlar ve eğitim kurumları gibi ideolojik olan medyanın bireyleri yönlendirme etkisi büyüktür. Toplumsal yapıyı şekillendirirken, toplumsal bilişi üreten bu ideolojik iktidar mekanizması ötekiler hakkındaki bilgiyi yayarak temsilleri denetler. ${ }^{19}$ Irksal eşitsizliğin yeniden üretilmesinde söylemsel-bilişsel hegemonyaya sahip medyanın rolü aşikârdır. Kültürel farkları olumsuz, niteliksiz, eksik olarak tanımlayarak kendini gösteren yeni ırkçı söylemlere yer veren medya, gücünü kötüye kullanmaktadır. Çünkü ırkçılığı sosyal ve bilişsel olarak; özellikle konuşma ve metinler yoluyla

15 Stuart Hall, “İdeolojinin Yeniden Keşfi: Medya Çalışmalarında Toplumsal Denetimin Kurulması ve Baskı Altında Tutulanın Geri Dönüşü”, Medya, İktidar, İdeoloji, der. ve çev., Mehmet Küçük, Ankara: Bilim ve Sanat Yayınları, 2005a, s.83-89; Stuart Hall, "Kültür, Medya ve İdeolojik Etki", Medya, İktidar, İdeoloji, der. ve çev., Mehmet Küçük, Ankara: Bilim ve Sanat Yayınları, 2005, 207-232.

16 Teun Van Dijk, "Söylemin Yapıları ve İktidarın Yapıları”, Medya, İktidar, İdeoloji, der. ve çev., Mehmet Küçük, Ankara: Bilim ve Sanat Yayınları, 2005, s.321.

17 İrfan Erdoğan ve Korkmaz Alemdar, Öteki Kuram, Ankara: Erk Yayınları, 2005, s.172-177.

18 Barış Çoban, "Medyanın Milliyetçi Söylemi: Medya, Öteki ve Şiddet” (Uluslararası Medya ve Siyaset Sempozyumunda Sunulan Bildiri, Ege Üniversitesi, İzmir, 15-17 Kasım, 2007, s.551-562).

19 Teun Van Dijk, “Söylem ve İdeoloji: Çok Alanlı Bir Yaklaşım”, Söylem ve İdeoloji, çev., Nurcan Ateş, haz., Barış Çoban ve Zeynep Özarslan, İstanbul: Su Yayınevi, 2015, s.44-45; Teun Van Dijk, "Söylemin Yapıları ve İktidarın Yapıları”, Medya, İktidar, İdeoloji, der. ve çev., Mehmet Küçük, Ankara: Bilim ve Sanat Yayınları, 2005, s.324. 
“öğreniriz”. Bu bağlamda medya söylemi bilgi, tutum ve ideolojilerin kaynağı olarak işlev görmektedir. Medya sembolik gücüyle; önyargıları, kutuplaştırıcı söylemleri, tehdit/sorun retorikleri, muhalif ve azınlıklara yer vermeyişi, ötekiler söz konusu olduğunda gösterdiği fikir birliğiyle belirleyicidir. ${ }^{20}$

Çeğin ve Meder ${ }^{21}$ sembolik şiddet mekanizmalarının işlediği ilişkiler ağının parçası olarak medyanın, iktidara eklemlenmiş yapısıyla sembolik şiddet uygulayarak söylemsel gerçeklik/doxa’nın belirlediği sınırlar kapsamında manipülatif "bilgi” sunduğunu vurgulamaktadır. Bu açıdan medya aracılığıyla uygulanan simgesel şiddetle sosyo-kültürel yapı şekillendirilmek istenmektedir. Özellikle televizyon yayınlarıyla kitlelerin manipülasyonu, iktidar söylemlerinin meşrulaştırılması, entelektüeller de dâhil olmak üzere medya aktörlerinin suç ortaklığıyla gerçekleştirilmektedir. Ötekiler hakkında yaygın inançlar olarak adlandırabileceğimiz stereotiplerin “öğrenildiğine”, medya gibi kurumsal kaynakların ilettiği bilgilerin gerçek-miş gibi kabul edilebileceğine dikkat çeken Bar-Tal, bazı durumlarda tek bilgi kaynağı medya olduğundan, iletinin tartışmasız biçimde kabul göreceğini vurgular. ${ }^{22} \mathrm{Bu}$ açıdan toplumsal bilinçdışını şekillendiren kitle iletişim araçları, ötekiler hakkındaki "etnik bilgi"yi yani-stereotipleri dolaşıma sokarak öğretmekle kalmaz, normalleștirir. ${ }^{23}$ Ötekinin bizden farklı olarak "acımasız, "hırsız", "cimri” veya "gamsız" olduğuna dair bilgi medyayla da öğrenilir, pekiştirilir ve biz’im dünyamızın sınırları bu tip bilgilerle güvenli kılınır. Medya, tarafsızlık ve gerçekliği yansıtma iddialarıyla önyargıları ve stereotipleri gerçekmiş gibi sunarak ${ }^{24}$ benimsenmesini kolaylaştırır.

\section{Yeni Medyada Şiddet ve Nefret Söylemi}

Nefret söylemini dilsel pratikler olarak tanımlarsak ${ }^{25}$ yoğun kullanılarak yaygınlaştığı yeni medya platformları önemlidir. ${ }^{26}$ Yeni medya, kullanıcıların özgürce içerik üreterek dolaşıma girdiği, gerçek hayattaki sınırların/sınırlamaların var olmadığı bir yapı sergilemektedir. Gelişen teknolojiyle sürekli yenilenen uygulamalar içermekte, orijinallik, etkileşimsellik, hipermetinsellik, yayılım, sanallık, multimedya biçemselliği gibi nitelikleriyle kullanıcıya içerik üretme imkânı sağlamaktadır. ${ }^{27}$ Öte yandan, yeni medyanın sınırsızlı̆̆ı ve dinamikliği üretilen içeriklerin denetimini zorlaştırmaktadır. Dolayısıyla yeni medya şiddet içeriklerinin serbestçe dolaşıma girmesine olanak sağlamaktadır.

20 Teun Van Dijk, “New(s) Racism: A Discourse Analytical Approach”, 2000, s.36-37, 48.

21 Güney Çeğin ve Mehmet Meder, "Sembolik Şiddet Arenası: Televizyon ve Medyatik Söylemin Özerkliği Sorunu”, Pamukkale Üniversitesi Eğitim Fakültesi Dergisi, 15/15 (2004), s.102-107.

22 Daniel Bar-Tal, "Formation and Change of Ethnic and National Sterotypes: An İntegrative Model”, International Journal of Intercultural Relations, 21/4 (1997), s.505.

23 Teun Van Dijk, Racism and the Press. London, New York: Routledge, 1991, s.21-26, 244.

24 Ülkü Doğanay, Ayrımcılık, Söylem ve Medya, Ayrımcılı̆̆ın Yüzleri, der. Ülkü Doğanay, Ankara: İHOP, 2018, s.24.

25 Nefret söyleminin belirli bir tanımı olmasa da Avrupa Konseyi Bakanlar Komitesi tarafından 1997 yılında alınan tavsiye kararı, siyasal, kadına yönelik, yabancı ve göçmenlere yönelik, cinsel kimliğe, inanç ve mezhebe, engelli ve hastalara yönelik nefret söylemlerini tasnif etmiştir.

26 Mutlu Binark, "Nefret Söyleminin İnternet Ortamında Dolaşıma Girmesi ve Türetilmesi”, Yeni Medyada Nefret Söylemi, haz., Tuğrul Çomu, İstanbul: Kalkedon Yayınları, 2010, s.25.

27 Tuğrul Çomu ve Mutlu Binark, "Yeni Medya Ortamlarında Nefret Söylemi”, Medya ve Nefret Söylemi, ed., Mahmut Çınar, İstanbul: Hrant Dink Vakfı Yayınları, 2013: 199-200. 
Nefret söylemi dilsel bir şiddettir; Agtaş, ${ }^{28}$ ancak dil dolayımıyla tanımlanabilen bireyin “ötekinin hitabına bağlı” bir varlık olmasından ötürü nefret söyleminin baskıcı, tehditkâr, imalı dil kullanımıyla yarattığı yıkıcılığa işaret eder. Dil belirli bir anlama hapsedebilir, bazı anlamları kapatabilir, dil bizi/ötekini "gösterir". Dolayısıyla dil psikolojik şiddet aracı olarak da karşımıza çıkar. Psikolojik ve sözel şiddet güç ilişkileri bağlamında, aşağılama, baskı ve kontrol, sınırlama, hakaret gibi biçimlerde kendini gösterdiğinden, ayrımcılık da psikolojik şiddet olarak değerlendirilmektedir. Nefret söylemi, psikolojik şiddetin söylemsel biçimidir. ${ }^{29}$

Yeni medyada farklı şiddet türleri izlenebilmekte, nefret söylemi kolaylıkla dolaşıma girebilmektedir. Geleneksel medyada örtük ve dolaylı yoldan işleyen nefret söylemi yeni medyada kullanıcı içerikleriyle doğrudan yer alabilmektedir. ${ }^{30}$ Nefret söyleminin yeni medyada hızla yaygınlaşmasının farklı nedenleri de bulunmaktadır. Sanal dünyaya sunulan sanal kimlikler, daha keskin ayrımlara dayanarak bu ayrımları vurgulamaktadır. Sosyal medyada benlik sunumlarını onaylatma ihtiyacındaki birey, baskıcı bir dille dini- politik simgeleri dolaşıma sokarak yoğun simgesel şiddet kullanabilmektedir. ${ }^{31} \mathrm{Bu}$ eğilimin beraberinde getirdiği kutuplaşma ve farkın olumsuzlanması kolaylıkla sosyal medya linçlerine dönüşebilmektedir. İnternet kullanımının ve mobil cihazların yaygınlaşmasıyla sosyal paylaşım ağlarının günlük hayata, dolayısıyla kimlik oluşumuna etkisine dikkat çeken Bakıroğlu ${ }^{32}$ ideolojik aygıtlarla şekillendirilen kimliğin artık sosyal medyayla daha hızlı dönüştüğünü, bireylerin beğenilme arzusuyla/bir güç olarak kimliğini inşa edip sunması bağlamında sosyal medyanın biz/öteki ayrımında etkili olduğunu belirtmektedir. Bu açıdan söz konusu ayrıma dayanan milli kimliklerin güçlenerek yeniden üretiminde internetin ve çeşitli platformlarla sosyal medyanın katkısı ortadadır. ${ }^{33}$ Nitekim internetin aşırı sağ söylemler tarafından etkili bir biçimde kullanıldığı, internet teknolojileriyle ırkçılığın ve yabancı düşmanlığının desteklendiği görülmektedir. Propaganda imkanıyla daha çok taraftar buldukları gibi şiddeti destekleyen içeriklerini kolay ve hızlı bir şekilde yaygınlaştırabilmektedir. ${ }^{34}$ Böylece irkçllık ve nefret suçu normal ve meşru hale getirilmektedir.

Esasen yeni medya nefret söyleminin çıkış kaynağı değil, toplumda egemen olan söylemin yansıdığı alan olarak değerlendirilmelidir. Toplumsal olgular, medya ve

28 Özge Agtaş, "Nefret Söylemi, Dilsel Yaralama ve Siyasal Faillik", Ayrımcılı̆̆ı Yüzleri, der., Ülkü Doğanay, Ankara: İHOP, 2018, s.77.

29 Teun Van Dijk, "Söylem ve İktidar", çev., Pınar Uygun, Nefret Suçları ve Nefret Söylemi, der., Özlem Dalkıran, İstanbul: Hrant Dink Vakfı Yayınları, 2010, s.33-34.

30 Hülya Öztekin, "Yeni Medyada Nefret Söylemi: Ekşi Sözlük Örneği", Uluslararası Sosyal Araştırmalar Dergisi, 8/38 (2015), s.926.

31 Hamit Ölçer, "Pierre Bourdieu Sosyolojisinde Simgesel Şiddet Sorunsalı ve Biçimleri", Nosyon: International Journal Of Society And Culture Studies, 2 (2019), s.43-45.

32 Cemile Toksöz Bakıroğlu, "Sosyalleşme ve Kimlik İnşası Ekseninde Sosyal Paylaşım Ağları" (XV. Akademik Bilişim Konferansında Sunulan Bildiri, Akdeniz Üniversitesi, Antalya, 23-25 Ocak, 2013, s.1050-1051).

33 Sercan Gidişoğlu ve Kerem Rızvanoğlu, "İnternette Türk Milliyetçiliği: Türk Milliyetçisi Siteler ve Ağ Yapısı Üzerine Bir Analiz", Nefret Suçları ve Nefret Söylemi, der., Yasemin İnceoğlu, İstanbul: Ayrıntı Yayınları, 2012, s.223-225.

34 Yaman Akdeniz, "İnternette Irkçllk", Nefret Suçları ve Nefret Söylemi, der., Özlem Dalkıran, İstanbul: Hrant Dink Vakfı Yayınları, 2010, s.177-192. 
egemen ideolojinin etkisi yeni medyada ifadesini bulmaktadır. ${ }^{35}$ Yeni medyanın denetimsiz ortamının sunduğu ayrıcalık, niyet ve düşüncenin gizlenmeden ortaya dökülmesine, yaygın bilginin ifşasına neden olmaktadır. Bilinmeyen öteki hakkında özellikle olumsuz önyargılar bu tip bilgilere dayanır. Bu açıdan günlük hayatta karşılaşma imkânı olmayan bireylerin, yeni medyayla bu imkânı bulması, ötekiyle her gün karşılaşması söz konusudur. Böylece yeni medya ifade özgürlüğü ve etkileşim fırsatıyla ötekine dair merak duygusunun giderilmesini sağlayarak ötekini tanıma fırsatı verebilmektedir. ${ }^{36}$ Elbette biz/öteki geriliminin ve önyargıların ortadan kalktığı karşılaşmalar mümkün olmakla birlikte, sosyal medyanın olumsuz yargıları pekiştirme ihtimalinin daha yüksek olduğu görülmektedir. İdeolojik aygıt medyanın ötekileştirici diliyle farklıyı hedef gösterdiği, zihinsel olarak yönlendirdiği toplumda önyargı, zenofobi, ırkçılık gibi nefret unsurlarını yeniden ürettiği, biz/öteki ayrımı temelinde şiddeti meşrulaştırdığ 1 görülmektedir. ${ }^{37}$ Yeni medyada bu üretim ve ötekileştirme hızla gerçekleşirken, kullanıcı içeriklerinin dokunulmazlığı nefret söyleminin dolaşımda uzun süre kalmasına ve sosyal medyanın paylaşımcı niteliği dolayısıyla etkisini güçlendirmesine neden olmaktadır.

\section{Ekşi Sözlük'te Nefret Dili}

Çeşitli araştırmalara göre Ekşi Sözlük, gündem yaratan ve haber sitesi gibi gündemin takip edildiği popüler sosyal medya platformlarındandır. Prensip olarak sansür yerine kullanıcıların öz denetimine bırakılan içeriklerinde hemen her konuda duygu ve görüşlerin dile getirildiği Sözlük'ün, bir anlamda kamuoyunu yansittığı da düşünülmektedir. Öte yandan nefret söyleminin Sözlük’te sık kullanıldığı görülmektedir. Gürel ve Yakın ${ }^{38}$ yeni medyada eğlencenin ötesinde algı üretip yönlendirme işlevinin geleneksel medyaya göre çok hızlı biçimde gerçekleştiğini ifade etmektedir: Dolayısıyla ötekileştirme pratikleri anında çok geniş bir kitleye ulaşabilmektedir. Özellikle Sözlük gibi kullanıcıların eğlenmek, vakit geçirmek ya da bilgi edinmek amacıyla kullandığı popüler uygulamalar, nefret söyleminin yayılımını hızlandırarak onu doğallaştırmaktadır.

Corona virüs/Covid-19'la tüm dünyada ve Türkiye’de ölümlerin gerçekleştiği, karantina uygulamalarının yürürlüğe konduğu süreçte Ekşi Sözlük’te Çinlilere yönelik nefret söyleminin arttığını varsayan bu çalışmada, Çin'in Wuhan şehrindeki ilk vakayı DSÖ’ye bildirdiği 31 Aralık 2019, yeni vakanın olmadığını duyurduğu 19 Mart 2019 tarihleri arasında Çin/Çinlilere yönelik içerikler incelenerek, / nasıl tanımlandıkları, ötekileştirici dilin kullanımı ve hangi temalarla ötekileştirme yapıldığg belirlenmiştir. Çalışma kapsamında site içi arama motorunda Çin/ Çinli anahtar kavramlarıyla tarama yapılarak bağlam kapsamında başlıklar seçilmiştir. Söz konusu kavramların

35 Tülay Yazıcı, "Yeni Medyanın Nefret Dili: Suriyeli Mültecilerle İlgili Ekşi Sözlük Örneği", Global Media Journal TR Edition, 7/13 (2016), s.123.

36 Torun, Ayla, “'Öteki' ile 'Biz' İlişkisinde Yeni Medya, Sosyal ve Beşeri Bilimlere ve Küresel Yaklaşımlar: Kuram ve Uygulamalar” (Uluslararası Sempozyumu, Varşova Polonya, 16-18 Eylül 2015: s.17).

37 Yasemin İnceoğlu, “Önsöz”, Nefret Suçları ve Nefret Söylemi, der., Yasemin İnceoğlu. İstanbul: Ayrıntı Yayınla$\mathrm{r} 1,2012$, s.17.

38 Emet Gürel ve Mehmet Yakın, "Ekşi Sözlük: Postmodern Elektronik Kültür", Selçuk Üniversitesi İletişim Fakültesi Akademik Dergisi, 4/4 (2007), s.203-219. 
yer aldığ 19 başlıkla, ${ }^{39}$ başlıklarda yer alan 1.100 girdi (entry), içerik analizi ve eleştirel söylem analiziyle incelenmiştir. İçerik analiziyle başliklar ve girdilerdeki kodlar belirlenerek sınıflandırılmış, oluşturulan temalarsa eleştirel söylem analiziyle değerlendirilmiştir.

Bell’e göre ${ }^{40}$ içerik analizi metin-görsellerle gerçekleştirilen temsilleri açıklama amacında olduğundan, olayın nesnel özellikleriyle hangi temalarla ele alındığı ve tekrarlanma oranı önemlidir. Söylem tasnif edilerek tekrarlanan içerik özelliklerinin anlamları değerlendirilir. Eleştirel söylem analiziyse "daha çok söylem, dil ve iletişim alanlarında etkin olan; otorite, ideoloji, sömürü, manipülasyonla hakimiyetin kötüye kullanılması gibi spesifik konulara yoğunlaşır”. Tahakkümün yeniden üretilmesine odaklanan bu analiz, günlük hayattaki konuşmalar dahil olmak üzere, söylemle yeniden üretilen olguları inceler. ${ }^{41}$ Eleştirel söylem analizinin makro boyutu konunun temalar kapsamında bağlamla değerlendirilmesini içerirken, mikro boyutuysa kelime seçimlerine, retoriğe odaklanarak makro boyutla birlikte değerlendirilerek ideolojik boyutu ortaya çıkarır. ${ }^{42}$

Uluslararası Hrant Dink Vakfı'nın raporlarında Türkiye’de nefret söylemi kategorileri, abartma/yükleme/çarpıtma; küfür/hakaret/aşağılama; düşmanlık/savaş söylemi ve doğal kimlik öğesini nefret ve aşağılama unsuru olarak kullanma/Simgeleştirme şeklinde dört grupta değerlendirilebilir. Ekşi Sözlük başlık/girdilerinde bu kategorilerin kullanıldığı saptanmıştır. Çoğunlukla olumsuz yargıların (778) küfür/hakaret/ aşağılama (246), olumsuz yönde ikna (306), abartma-çarpitmalarla sunulduğu, nefret söylemi kategorileri bağlamında seçilen başlık/girdiler değerlendirildiğindeyse, şu çerçevede bir söylem görülmektedir:

1) Düşmanlık/savaş söylemi hâkim temalardandır. Çin/Çinlilerin tehdit unsuru olarak değerlendirildiği altı tema saptanmıştır:

a. Yaşam Tarzı/Kültürel Tehdit

b. Nüfus Tehditi

c. Virüs/Salgın Tehditi

d. Küresel/Ekolojik Tehdit

e. Ekonomik Tehdit

f. Siyasal Tehdit

a. “Tehlike” vurgusunun 81'inde kullanıldığı, Wuhan'ın yemek kültürünün ${ }^{43}$ Çin’in tamamına mal edilerek "tehlike” olarak görüldüğü anlaşılmaktadır. Yazarların ifa-

39 Başlıklar: Çin/ Çinli/ Çin Halk Cumhuriyeti/ Çinlilere Karşı Irkçıyım/ Chinese Virus/ Şu An Tüm Dünyanın Çinlilerden Nefret Ediyor Oluşu/ Çinlileri Ülkemizde İstemiyoruz Kampanyası/ Çin Virüsü/ Düşün ki Bir Çinli Bunu Okuyor.

40 Philip Bell, “Content Analysis of Visual İmages”, The Handbook of Visual Analysis, ed., Theo Van Leeuwen, Carey Jewitt, London: Sage Publications, 2001, s.13-17.

41 Van Dijk, "Söylem ve İktidar", s.10-11.

42 Van Dijk, Racism and, s.x, 45-47,178.

43 Wuhan yemek kültüründe tüketilen egzotik hayvanların Çin geleneksel tıbbında kullanıldığı bilinmektedir. Geleneksel Çin mutfağının küçük bir bölümünde yaygın olan bu eğilimin imparatorluk zamanından kalma bir sunum kültürü olduğu, ülkede yaşanan büyük kıtlıklar neticesinde halkın yaşama mücadelesiyle geliştiği bilinmektedir. 
deleriyle "her şeyi yiyen”, “pislik yayan”, “tehlike saçan” Çin’in “akıllara zarar, rezil, saçma sapan inanışları" ve "gelenekleri tehdittir". "Yaşam tarzları"yla "insanlığa savaş açan” Çinliler, "insanlığın sonunu getirebilir”. Sergilenen tutum kültürel fark nedeniyle ötekileştirme örneğidir. Van Dijk’a göre ${ }^{44}$ kültürel farkların “sapkınlık”la ilişkilendirilmesi yeni ırkçılıktır: dil, gelenek, giyim-kuşam, din gibi kültürel özelliklerle fiziksel görünümlerin "olumsuz" tasnif edilmesi etnik konumlandırmadır. ${ }^{45}$ Kültür hiyerarşisiyle alt-grupları kültürel yoksunluk/gerilikle ilişkilendiren veya hiyerarşiyi reddederek farklılıklardan ötürü birlikte yaşamayı imkansız gören yeni ırkçılıkta kültürel fark tehdittir. ${ }^{46}$

Irkçı söylem etnik/farklı ötekine yönelik ve etnik/farklı öteki hakkında yansır. Birincisi doğrudan ayrımc1 pratiklerle görünürken, ikincisi "hafifletilmiş" dozda irkçllık içerir. Zira ırkçılığın yanlış bir davranış olduğu aşikardır. Bu nedenle saygısız tutumlar, tonlamalar, mimikler, kelime seçimleri, çeşitli retoriklerle açığa çıkar. Ötekilerin farklı/biz’den ne kadar uzak olduğuna dair niteliklerini, sapkınlığını, bizim değerlerimizi ihlal ettiğini vurgulayarak veya tehdit olarak nitelendirip, suçla ilişkilendirerek işleyen yeni ırkçı-tehdit söylem bireysel değil, sosyal grubun/biz'in beyanıdır. ${ }^{47}$ Sue ve arkadaşlarına göre ${ }^{48}$ rkssal temelli mikro fiili saldırı, ötekini değersizleştirmeye, küçük düşürmeye yönelik bilinçli söz/eylem biçimi, modern/ yeni irkçılık olarak tabir edilir, genellikle kültürel farklılıklar üzerinden işleyerek tarihsel-kültürel olarak değişken anlamlar taşıyabilir. Çinlilerin yaşam tarzları, yemek kültürleri, gelenekleri tehlike olarak böylelikle kodlanabilmektedir.

b. Çin, nüfus yoğunluğuyla dünyanın en büyük ülkelerinden olduğundan tehdittir: nüfusunu avantaj olarak kullandığı, büyük nüfusuyla "baş edilemez" olduğu sıklıkla vurgulanmıştır. "İt gibi üremişler”, "çoğalmışlar da çoğalmışlar” nitelendirmeleriyse dehumanizasyona işarettir. Çin’in nüfusunu ekonomik kalkınma ve ordu gücü olarak "avantaj” çevirdiği düşünülmektedir. Bu nitelikleriyle Türkiye için bir tehlike arz etmektedir:

“o kadar hızlı büyüdüler ki geldikleri zaman kaçacak yerimiz olmayacak” (Yazar-1).

c. Bu bağlamda Çin'in sadece bugün değil, tarih boyunca salgın yaydığı düşünülmektedir. Sars, kuş gribi, İspanyol gribi, Rus gribinin Çin kaynaklı olduğuna, Orta çağa

44 Van Dijk, Racism and, s.26.

45 Ötekinin fiziksel özellikleriyle kolayca tespit edildiği klasik ırkçılığın aksine, etnomerkezcilik ve kültüralizmin yabancı düşmanlığıyla birleşmesine dayanan yeni ırkçılığın kültüre odaklanması tespitini güçleştirmektedir. Irkla kültürün özdeş görülmesi dolayısıyla, değişmez niteliklere sahip olunduğuna dayanan yeni ırkçılık, farklı kültüre saygı söylemiyle kendini gösterse de herkesin kendi sınırlarında kalması gerektiğine dair eşitsizlik inancından temellenir. Bkz. Ahu Sumbas, "Batı Avrupa'da Yükselen Irkçılık Üzerine Bir Deneme”. Alternatif Politika, 1/2 (2009):267-270.

46 Hatice Çoban Keneş, "Yeni Irkçı Söylemlerin Eklemli Niteliği ve Medyanın İşlevi”, Ankara Üniversitesi, SBF Dergisi, 69/2, (2014):411-423.

47 Teun Van Dijk, "Discourse and Denial of Racism", DiscourseઐSociety, (1992): s.115-116. "Racist Discourse”, Routledge Encyclopedia of Race and Ethnic Studies, ed., Ellis Cashmore, London: Routledge, 2004, s.351-352.

48 Derald Wing Sue, C. M. Capodilupo, G. C. Torino, J. M. Bucceri, A. M. B. Holder, K. L. Nadal ve M. Esquilin, "Racial Microaggressions in Everyday Life: Implications for Clinical Practice". American Psychologist, 62/4 (2007), s. 271-286, aktaran Serdar Ünal, "Irksal Temelli Ayrımcılığın Yeni Görünmez Yüzü: Kültürel Karşılaşmalar ve Mikro Saldırganlıklar”, Journal of Social and Humanities Sciences Research, 5/28 (2018). 
damgasını vuran vebanın Çin'den yayıldığına inanılmaktadır.

"Vebalı hastaları İpek Yolu’ndan zorla göçe zorlarmış" (Yazar-2).

Ötekinin sıra dışı olaylarda günah keçisi olarak nitelendirilmesine sıkça rastlanır. Bu bağlamda Çin "dünyayı enfekte eden", "dünya için tehdit ve felaket" olan, "dünyanın başına yeni tip bir virüs saran", "virüsü bela eden" ülke olarak tasvir edilmekte, "nükleerden beter" virüsü silah gibi kullandığı düşünülmektedir.

d. Çin'in sanayi-teknoloji açısından gelişmişliği ve nüfusuyla küresel eko-sisteme tehdit oluşturduğu söylemler arasındadır. Çin, doğal kaynakları "aşırı" tüketerek, "talan" ederek doğaya zarar vermektedir. Pandemide uyguladığı sert politikalar, başta kendi halkı olmak üzere insanlara, yemek kültürüyle hayvanlara değer vermediği örneklendirilerek, "dünyanın çivisini çıkaran", "insan-hayvan haklarını tanımayan" Çin, bir yazarın ifadesiyle "dünyanın beka sorunu"dur. Bu söylem, ötekinin günah keçisi olarak görülmesinin ve olumsuz nitelendirilen gücünün abartılmasina örnektir, zira diğer ülkelerin ekolojik sisteme verdiği zarar göz ardı edilerek, sadece Çin "aşırı" sanayileşmesi- tüketimiyle sorumlu tutulmaktadır.

e. Dünya ekonomisinin güç unsurlarından Çin'in bilişim sektöründe gerçekleştirdiği atılımlar, "süper güç" olarak görülmesinde etkilidir. Yazarlar durumu oldukça tehlikeli görmektedir, zira Çin, nüfusundan kaynaklanan üretim ve askeri gücü, "yayılmacı" yönetimiyle dünya için tehdittir, daha fazla "güçlenmemeli"dir.

“...o kadar güçlüler ki, o kadar sağlam adımlarla geliyorlar ki çok değil 50 sene sonra gelmiş geçmiş en büyük küresel güç olacaklar” (Yazar-3).

"Çinlilerse tam aksine 10.000 yıldır yerleşik kültürde yaşayan ve asimile olmayan bir toplum. Dolayısıyla yayılmacı politikaları dünyamız için çok daha tehlikeli olacaktir." (Yazar-4).

“...sıkıştığı zaman tehlikeli oyunlar oynamaktan kaçınmayan bu ülkeyi dünya tamamen izole etmeli” (Yazar-5).

f. Çin siyasal bakımdan da tehdittir: "aşırı silahlandığı", halkına karşı "acımasız politikalar" yürüttüğü, "yayılmacı/istilacı" olduğu vurgulanmaktadır. Çin rejimi tehdittir: "komünizm virüsü" nitelendirmesiyle, komünizmle gelen "tehlike" olarak ateizmin görülmesi ideolojik söylemin yansımasıdır.

2) Düşmanlik-savaşs söylemine paralel, tarihi-dini referanslarla ikna retoriği oluşturulmaktadır. Van Dijk, bir strateji olarak söylemlere, sözcük seçimlerine ve vurgulara yansıyan retoriğin ideolojik söylemle alakalı olduğunu belirtir. ${ }^{49}$ İncelenen 1100 girdinin 306'sı ikna çabasındadır. Tarihi referanslarla Çin "eski-ezeli düşman" olarak nitelendirilmektedir: eski Türk kaynaklarında "Hitaylar" olarak geçen Çinlilerin Türklere tepeden baktıkları, Göktürk Kitabelerinde Bilge Kağan’ın ögütlerine referansla Türklerin en büyük düşmanı oldukları hatırlatılmaktadır. Bir yazar "Cengiz Han yarım bıraktı bu işı” demektedir. Bazı yazarlara göre "Atalarımız zamanında

49 Van Dijk, Racism and, s.216-217. 
bunların hakkından tam gelememiş”tir ve “3000 sene boşuna savaşmamış”tır. Başka biri "keşke Metehan vergiye bağlamak yerine soyunuzu kurutsaydı" ifadesini kullanmaktadir. ${ }^{50}$

Türklere varsayılan düşmanlık, Uygur Türkleriyle Çin arasındaki gerilimle de ilişkilendirilmekte; Doğu Türkistan'daki sert politikalar, Türklere ve İslam’a karşı varsayılan tarihi nefretle açıklanmaktadır. Girdilerde Uygurlara işkence, asimilasyon/ soykırım yapıldığı, "patolojik düzeyde" Türk- İslam düşmanlığı sıkça dile getirilmektedir. Bar-Tal, gruplararası ilişkilerin dinamiğine bağlı olarak, sosyo-ekonomik ve tarihi bağlamların; savaşlar, düşmanlıklar ve dostlukların stereotip oluşumundaki önemine dikkat çeker. Bazen dost/düşman ayrımı farklı şekilde işler: dostumun dostu/düşmanı biz’im dost/düşmanımızı belirler ${ }^{51}$ Bu bağlamda Çin-Uygur ilişkisi yazarların Çin’e bakışında belirleyicidir. Tarihi ilişkiler stereotipleri etkiler; ötekiyle karşılaşmalar unutulmaz, nesilden nesile aktarılarak kolektif belleğe yerleşir. Karşılaşma anlarında seçici biçimde hatırlanan bilgiler ilişkilerin çerçevesini belirler. ${ }^{52}$ Türklerin tarihi/ezeli düşmanını anımsatan girdiler, nefret söyleminin ideolojik olduğunu göstermektedir. Türkiye geçen binlerce yıla ve coğrafi uzaklığa rağmen hala Çin’in tehdidi, dolaylı yollarla işgali altındadır.

İkna metodu olarak dini referanslardan en sık kullanılanı, İslam ve Yahudi mitolojisindeki kıyamet alameti yaratıklar "Yecüc-Mecüc"/"Gog-Magog"tur. Kutsal kitapların referansıyla Çinliler, nüfus yoğunluğu, ima edilen gücü ve fiziksel özellikleri ileri sürülerek insanlığın ve dünyanın sonunu getirecek mitolojik yaratıklar olarak tanımlanmaktadır. Mitolojik yaratıklarla fiziki benzerlikleri çeşitli ayet-hadislerle, "alametlerin" Tevrat'ta da geçtiği hatırlatılarak kanıtlanmaya çalışılmaktadır. Bu retorikle Çin'in İslam düşmanı olduğu yine "kanıtlanmış” olmaktadır. Canavarlarla/ insandışı yaratıklarla ilişkilendirilerek dehumanizasyonun da örneğidir.

3) Komplo teorileri ikna retoriğidir. Günah keçisi Ötekinin hain planlarına odaklanan komplo teorileri, ötekinin gücünün abartılmasına da dayanır. Teoriler sınıflandırıldığında aşağıdaki temalar görülmektedir:

a. Çinliler hastalığı bilerek yaymıştır: Nüfus maliyetini ortadan kaldıracak; ekonomisindeki “yaşlı yükü”nü hafifletecektir. Pandeminin dünya ekonomisinde yarattığ krizi öne sürenlere göre, salgını atlatarak nüfus/işgücüyle kısa sürede ekonomisini toparlayacak olan, pandemiden "karlı" çıkan Çin, ABD'yle rekabeti ve ticari kaygıları dolayısıyla virüsü "biyolojik silah” olarak kullanmaktadır. Aşıyı bulmuştur, "dünya kırılsın" diye sessiz bir bekleyiştedir.

“biyolojik silah niteliğindeki vahşi hayvan pazarlarını kapatmıyor” (Yazar-6).

"biyolojik silah olarak vatandaşlarını kullanma ihtimali olan ülke” “(Yazar-7).

50 “Çin virüsü” çıkışıyla gündem yaratan ABD Başkanı Trump’ı “21. yy. Kürşad'ı” olarak nitelendiren girdi dikkat çekicidir: Mitolojide Kürşad, Çin Seddi’ni yıkmıştır.

51 Bar-Tal, "Formation and", s.504.

52 Bar-Tal, "Formation and", s.500-501. 
“o zaman başka bir oyun var diye düşünüyor insan... tamamen bir Çin satrancı” (Yazar-8).

Stratejisiyle dünya ekonomisini ele geçirecek,"bağımlı” kılacak, “sömürgeci” bir devlettir; artık "tabutta bile Made in China yazıyor"dur. Çin'in dijital dünya modeliyle pandemiyi firsata çevirdiği bir "Yeni İpek Yolu Projesi” olduğu iddiası, 5G iletişim kontrolü olarak tanımlanmaktadır. Bu varsayım pandemi sürecindeki dijital denetimi örnek gösterilerek meşrulaştırılmaktadır.

“...ödüllü-denetimli vatandaşlık sosuna bulandırılmış yeni dünya düzeninde başat oyuncu yeni Çin'e hazırlanın!” (Yazar-9).

Ötekinin gücünün abartılması diyebileceğimiz bu bakış açısı, Çin’in Türkiye üzerindeki emellerine işaret etmektedir: Kanal İstanbul, III. Hava Limanı ihalelerine giren Çin, Türkiyeyi sömürgeleştirmeyi hedeflemektedir. Nitekim Çinli turist "istilası” metaforuna rastlanmıştır. Diğer iddia, bölgesel denetim niyetiyle virüse göz yumduğudur. Böylelikle Çin, Hong-Kong gibi özel bölgeleri denetleyebilecektir, zaten Wuhan da bölgeye yakındır.

b. Çin’in vurdumduymazlığı, beceriksizliği nedeniyle pandeminin yayıldı̆̆ına dair inanca göre Çin komünist parti politikaları yüzünden salgını yenemediği gibi DSÖ’yü yanıltarak örtbas etmektedir. Diğer iddia DSÖ’nun tarafgirlikle Çin lehine verileri örtbas ettiğidir. Yazarlar Çin'i sinsilikle tanımlamaktadır.

"Wuhan propagandasını çok güzel uyguluyorlar. Hiç güven vermiyorlar." (Yazar-10).

c. Bazı güçlerin biyolojik silah olarak virüs kullandığına dair inanç: salgının kasten, ABD, İsrail, küresel güçler, "global çete”, "illuminati” tarafından çıkarıldığı iddia edilmektedir. ABD tazminat planıyla Çin’i savaşmadan ortadan kaldırma çabasındadır. Öteki yelpazesini göstermesi bakımından önemli olan yorumlar bir beklentiye; ötekilerin iş birliği yaparak sinsi planlarını eyleme geçirebileceğine dairdir: tetikte olunmalidir.

4) Doğal kimlik öğesini nefret-aşağılama unsuru olarak kullanma /Simgeleştirme bağlamında fiziksel özelliklerin aşağılandığı görülmektedir. "Asık yüzlü”, “yerden bitme”, "yarım yamalak", "pigme”, "çekik gözlü/çekik” ifadeleri oldukça sıktır. Fiziksel aşağılamalar ırkçı söylemlerin unsurlarından olup dehumanizasyon ve intra-hümanizasyon öğeleri içermektedir. Dehümanizasyon, ötekinin insanlıktan çıkartılma biçimlerini kapsar. Haslam'a ${ }^{53}$ göre insanlıkdışı kategorilerle çoğunlukla şeytan, canavar gibi kötücül yaratıklara atıf yapılır. Yaygın bir dehumanizasyon türü de hayvan olarak tasvirdir. İnsanlığının tamamen reddedildiği bu tarz söylemlerle ötekine hayvani özellikler yüklenir. ${ }^{54}$ Kitlesel "imhası” böylelikle meşrulaştırılabilir.

Sözlük’te beslenme kültürünün farklılığıyla ötekileştiren Çinliler “hayvan” olarak nitelendirilmektedir: yemek yerken "lama gibi tüküren” Çinli, "leşçi”, "leş yiyici”dir.

53 Nick Haslam, "Dehumanization: An Integrative Review", Personality and Social Psychology Review, 10/3 (2006), s.254.

54 Haslam, “Dehumanization”, s.252-254. 
S1kça rastlanan hayvani özelliklerden “üreyen”, “yiyip yiyip çiftleşen güruh” ifadelerine göre tehdit "nüfusları"dır. "Güruh" kelimesi başka bir kategoriyi göstermektedir: "korkunç yaratıklar”, "canlı her şeyi yiyen” canavarımsı bir tür olarak nitelendirilen Çinliler "hanibal ırk”tır. Yazarların bazıları "nasıl bir türsünüz” diye sorarken, bazıları cevaplamaktadır: Çinliler "farklı bir tür gibi”"dir, "alt insan formu”dur, açıkça “insan değil"dir; "insanımsı topluluk"tur. Bazı yazarlar Çinlilere "insan olun", "daha insani olsalar", "insan gibi beslenin" diye seslenmekteyken, ${ }^{55}$ bazılarında Çinliler "garip", "tuhaf", "uzaylı gibi"dir. Bir yazarın açıkça ifadesiyle "Çinli virüstür".

Dış grubun insani özünün reddi olarak intra-hümanizasyonda temel alınan iki insani duygudan birincisi insanı benzersiz kılan özellikleri kapsayan Human Uniqueness/ HU, diğeri insan doğasını kapsayan Human Nature/HN'dir. HU özellikler medeni olma, nezaket, ahlaki hassasiyet, rasyonel olma, olgunluk olarak siralanabilir. Ötekilere hayvani özellikler yüklenirken HU nitelikleri reddedilir: öteki kültürel olarak geri-ilkel, kaba, ahlaksız, irrasyonel ve çoğunlukla içgüdüsel davranış sergileyen, çocuksu- özdenetimden yoksun bir türdür. ${ }^{56}$ Sözlük’teki sıfatlara bakıldığında, stereotiplerin büyük kısmı intra-hümanizasyon içermektedir. Çinliler "hilekar", "sahtekar", üç kağıtçı”, kopyacı" hırsız” ahlaksız", "yalancı” açgözlü”, "sinsi”, “fırsatçı”, "çıkarcı”, "entrikacı", "materyalist" olarak çeşitli ahlaki stereotiplerle adlandırılmakta, bazı girdilerde "onursuz", "kültürsüz", "ilkel”, "faydasız medeniyet”, “cahil”, “yaşam tarzı leş”, "medeniyetsiz" tabirleri kullanılmaktadır. Çinlilerin nüfusu için kullanılan "üreme” tabiri hayvani içgüdüsel davranış sergileme bakımından görülebilir. Intra-humanizasyonun diğer biçimi insani doğasının/HN reddidir. Duyarlı, sosyal ilişkileri güçlü-sıcak, açık fikirli, bireyselliği gelişmiş-özgün, derinlik taşıyan bir canlı olma özelliğini taşımayan öteki tam tersine durgun-tepkisiz, soğuk, sert, pasif ve kişiliksiz, yüzeysel olarak resmedilir. Ötekinin HN değerler taşıdığının inkarı mekanikleştirme, onu bir otomat gibi varsayma olarak karşımıza çıkar. ${ }^{57}$ Nitekim Sözlük’e girilen girdilere bakıldığında Çinlilerin "canlı robot", "robotlaşmış" olarak tabir edildikleri görülmektedir.

Kullanılan stereotipler ahlaki/ kültürel/ fiziksel/zihinseldir, ahlaki olarak olumsuz nitelikler yüklendiği; ayrıca insani duygulardan arındırılarak tanımlandıkları görülmüştür.

Tablo 1. Çinlilere Yüklenen Ahlaki Stereotipler

\begin{tabular}{|l|l|}
\hline Zalim & Egoist/bencil \\
\hline Merhametsiz & Empati yoksunu \\
\hline Acımasız & Sorumsuz \\
\hline Duygusuz & Vicdansız \\
\hline Riyakar/iki yüzlü & Gaddar \\
\hline
\end{tabular}

55 Bir yazara göre Çinliler “insan değil...bunun kültürle kıtlıkla açlıkla bir ilgisi yok. Bunlar homo sapiens değil bunlar başka bir tür...bütün insanlık birleşmeden bu ne olduğu belirsiz türün hakkından gelmek de imkansızdır... Wuhan pazarında kafasına sopayla vurulup kaynar kazana atılan bir kedi değil siz olabilirsiniz."

56 Haslam, "Dehumanization", s.255-257.

57 Haslam, "Dehumanization”, s.257. 


\begin{tabular}{|l|l|}
\hline Utanmaz/arlanmaz & Yezit \\
\hline Umursamaz & İnsafsız \\
\hline
\end{tabular}

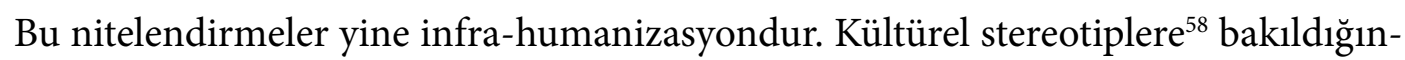
daysa, ağırlıkla Çin yemek kültürü/yeme alışkanlıklarına yönelik olduğu görülmektedir. Bu doğrultuda Çinliler "pis” (38), "pislik" (16), "midesiz" (21) olarak tanımlanmaktadır. Ayrıca "iğrenç”, "pisboğaz”, her şeyi yiyebilen, "yamyam/yamyam sürüsü/ modern zaman yamyamları/yamyamdan beter" "vahşi”, "Asya oburu” ve "tiksinti veren/tiksinilen bir millet” tabirleri kullanılmıştır. Stereotiplerin yansıtma mekanizması düşünülürse, kötü/olumsuz nitelikler ötekilere, iyi/olumlu nitelikler biz’e aittir: entrikacı/ahlaklı, pis/temiz, zalim/merhametli gibi karşıtlıklar çerçevesinde Çinli neyse biz tam tersiyizdir.

Ötekinin zihinsel yetersizliğini vurgulayan ırkçı söylemlere de rastlanmaktadır. Çinliler "aptal”, "idrak edemeyen” "yarım akıllı/akılsız", geri zekalı", "sapkın”, "ruh hastası", "psikopat/manyak" olarak etiketlenmiştir. Yazarın ifadesiyle, "rahatsız ve (fakat) güçlü” bir toplum olarak "tehlikeli” kodlanan Çinlilere karşı dikkatli olunmalıdır. Sözlükte kullanılan bu dil, Sue ve arkadaşlarının ${ }^{59}$ ifade ettiği yeni ırksal temelli mikro saldırganlık/mikro aşağılamaya örnek gösterilebilir. Ötekinin kültürel değerlerinin "hastalıklaştırılması” olarak karşımıza çıkan bu ırkçılık, "suçlu” ve "sapkın” kodlanmasını, zeka düzeyinin "aşağı” varsayılmasını da içerir. Böylelikle kültürel kimliği değersizleştirilerek ırksal hiyerarşide alt sıralara itilmiştir.

5) İyi/kötü Çinli ayrımı görülmektedir. Çinli kültürel farka dayalı tanımlanmıştır: iyi/kötü "Yarasa yiyen/ yemeyen" ya da "ot çöp böcek yiyenler bazı kesimler” üzerinden, siyasi ideoloji üzerinden "komünistler/ komünist olmayanlar” şeklindedir, Çin’in planlarından "habersiz olanlar", doktorlar, sağlıkçılar da Kötü Çinlilerin d1şındadir.

Bir başka unsur, Van Dijk’’n vurguladığı, etnik fark karşısında hoşgörülü, empatik, adil bir yaklaşım sergilendiğine dair kullanılan stratejilerdir: öteki örtük-muğlak biçimde imalarla olumsuzlanmaktadır. ${ }^{60}$

"Pisler ama (iyileri de var)" (Yazar-11).

"Haklılık var, ama (iyileri de var)" (Yazar-12).

"Vahşiler ama (iyileri de var)" (Yazar-13).

58 Bar-Tal özellikle etnosentrik-olumsuz sterotiplerin dış grubun farkları ile korku uyandırdığında zaman oluştuğuna dikkat çekmektedir. Bar-Tal, "Formation and”, s.499.

59 Sue vd., "Racial Microaggressions in Everyday Life", aktaran Serdar Ünal, "Irksal Temelli”. s.3295.

60 Van Dijk, "Discourse and Denial”, s.115-116; Van Dijk, Racism and, s.187. 
6) Çin tehdidine karşı önerilen çözümler nefret söylemi ve ırkçı öğeler içermektedir.

Tablo 2. Çözümler

\begin{tabular}{|c|c|}
\hline İntikam/Savaş/İşgal söylemi & 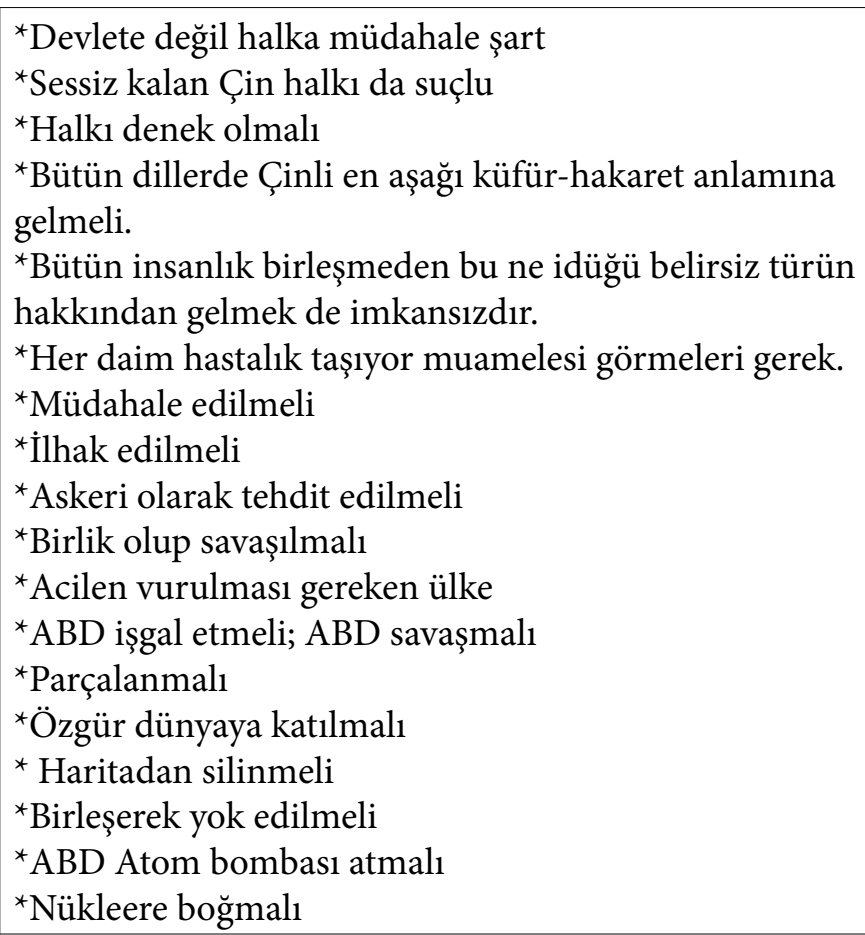 \\
\hline $\begin{array}{l}\text { Ekonomik/siyasal/sosyal } \\
\text { yaptırım söylemi }\end{array}$ & 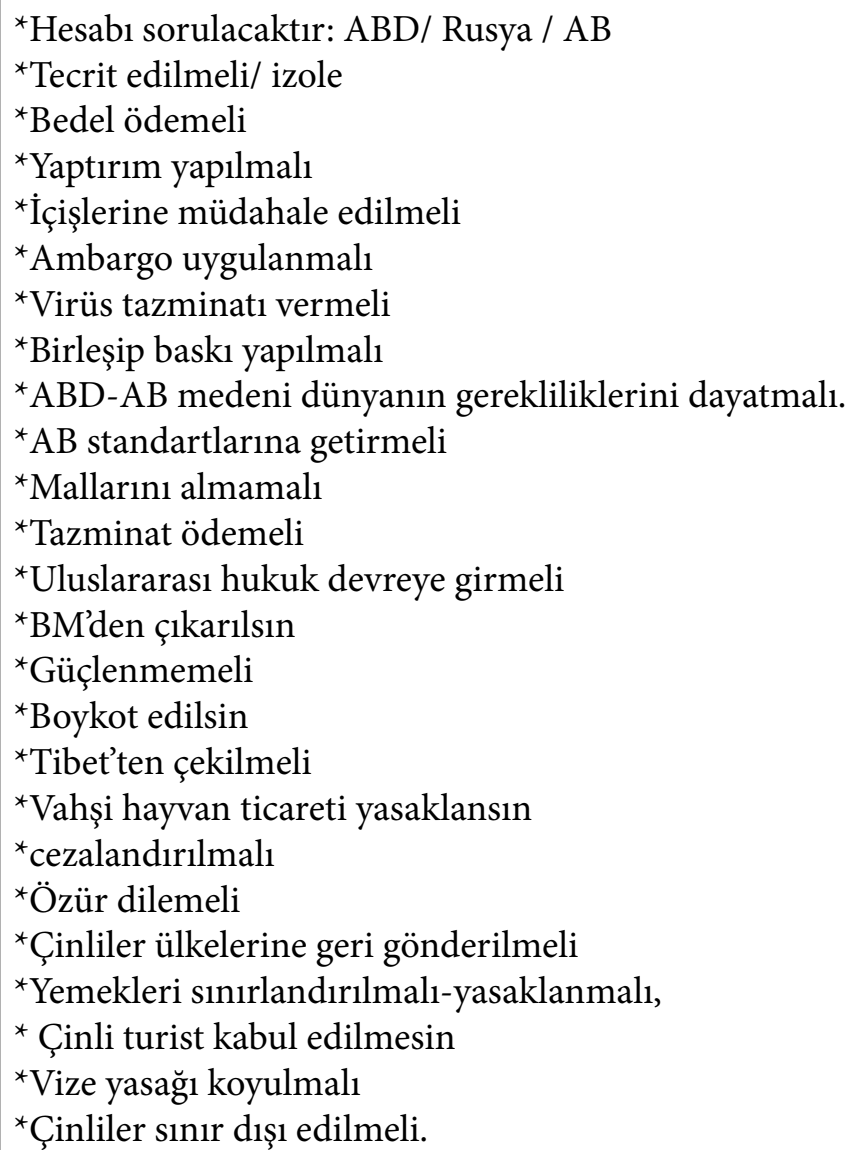 \\
\hline
\end{tabular}


7) Yeni ırkçı söylemin ayırt edici özelliklerinden biri mizah retoriğidir. Girdilerin 48'inde aşağılayıcı söylemlerin bazen küfür-hakaretle birlikte "komik" şekilde sunulmaya çalışıldığı görülmüştür: yemek kültürünü yermek için ezogelin çorbası tarifi vermek gibi. Eğlenmek için kullanılan ve içerik üretilebilen sosyal medyada bir "iletişim biçimi”; mesaj veren, düşüncelerin iletilmesini sağlayan bir araç ${ }^{61}$ olarak mizah önemli yere sahiptir, fakat biz/öteki ayrımına bağlı olarak ötekinin dışlanmasında da kullanılabilir, bu bakımdan sosyal ilişkileri düzenleyici bir rolü bulunmaktadır. Bireylere "söylenemeyenleri söyleyebilme"; ötekiler hakkındaki düşüncelerini çekinmeden dile getirebilme olanağ 1 da veren mizah "sevilmeyeni göstermenin bir yolu"dur. ${ }^{62}$ Mizahla işleyen yeni irkçılığın, tespit edilmesi zordur. ${ }^{63}$ Dolayısıyla mizahı her zaman masum olarak değerlendirmekten ziyade, güç ilişkilerini yansıtan bir mekanizma olarak görmek yerindedir.

\section{Sonuç}

Medyanın ticari kaygılarıyla araçsallaştırılarak günlük hayatımızın parçası haline getirilen şiddet, öğrenilen bir olgudur. Egemen değerleri gerçeklik olarak sunan medya, toplumdaki bölünmüşlüğü yeniden üreterek, bir denetim mekanizması kullanmakta; ürettiği temsillerle toplumsal hayatın sınırlarını hatırlatmaktadır. Geleneksel medyanın yanı sıra yeni medyada da şiddet kullanılmakta, teknoloji sayesinde çok daha hızlı yayılarak normalleşmektedir. Dilsel şiddetin bir biçimi olarak nefret söylemi, doğrudan ırkçılıkla birlikte örtük işleyen yeni ırkçılığın da göstergesi olup, aynı oranda yıkıcı sonuçlar doğurabilir. Geleneksel medyanın örtük dilinin aksine, yeni medyada anonimliğin verdiği rahatlıkla sert biçimde ${ }^{64}$ kullanılan nefret söylemi güçlü bir şekilde yeniden üretildiğinden, sosyal medya içerikleri önem taşımaktadır.

Bu çalışmada medyada şiddet olgusu bağlamında, yeni medyada yaygın şiddet türü olan nefret söylemi incelenerek Ekşi Sözlük'te Çinliler hakkındaki nefret söylemi belirlenmiştir. Çin'deki durum, insani destek, hangi önlemlerle salgının önüne geçilebileceğinden ziyade pandeminin “şeytani” bir güç atfedilen Çin’in merkezinde olduğu komplo teorileriyle ilişkilendirildiği, teorilerin milliyetçi-dini referanslarla desteklendiği, Çin kültürünün yerilerek Çinlilerin ötekileştirildiği görülmektedir. Çin/Çinlileri ötekileştirici söylemlerin çeşitli biçimlerde yeniden üretildiği Ekşi Sözlük’te yorumlar aşağılayıcı nitelikte olup hakaret-küfür içermekte, stereotiplerle önyargılara dayanmaktadır ve çoğunlukla günlük yaşamında bir Çinliyle karşılaşmamış bireylerin söylemleridir. Türkiye'de hakim ideolojik söylemden izler taşımakta, resmi tarih söyleminde Çinlilere dair sunulan "bilgi”" devreye girmektedir.

Ekşi Sözlük, Türkiye’nin sosyo-politik koşulları göz önüne alındığında fikirlerin özgürce söylenebileceği ortamılla, kullanıcıların gerçek yaşamda dile getiremedikleri

61 Duygu Ergün Takan ve Müjgan Yağmur İçelli, “Dijital Mizah”, Medya ve Mizah, der. Huriye Kuruoğlu ve Mikail Boz, Ankara: Nobel Akademik Yayıncılık, 2016, s.501-510.

62 Meşe, Gülgün. "Mizah ve Sosyal Psikoloji”, Medya ve Mizah, Huriye Kuruoğlu ve Mikail Boz, Ankara: Nobel Akademik Yayınc1lık, 2016, s.85-87, 91.

63 Doğanay, "Irkçılı̆̆ın İzini”, s.159-161.

64 Doğanay, “Ayrımcılık, Söylem”, s.36. 
düşüncelerini ifade edebilecekleri bir platformdur. ${ }^{65}$ Bu bağlamda Sözlük’te yer alan nefret söylemleri öteki hakkında dile getirilemeyeni göstermektedir. Çin/Çinlilerle ilgili denetimsiz ve sansürsüz ortamda sunulan söylemlerin Türkiye kamuoyunun genel algısını yansıttığ 1 düşünülebilir.

Stereotiplerin davranışları yönlendirdiği bilinmektedir. ${ }^{66}$ Dolayısıyla, medyada üretilen nefret söylemi ayrımcılığa ve yok edici bir şiddete yol açma potansiyeli barındırmaktadır. Ekşi Sözlük’te gördüğümüz yeni ırkçı/mikro-saldırgan tutumlar, uygun koşullarda şiddete dönüşebilir. Bu potansiyeli düşünüldügünde, bir arada yaşama kültürünün; demokrasinin ve toplumsal barışın önünde bir engel olarak nefret söylemi, öncelikle tanımlanmalı, ifade özgürlüğüyle farkı belirlenmeli ve bu doğrultuda denetim mekanizmaları oluşturulmalıdır. Medya okur yazarlığının geliştirilerek nefret söylemine karşı bilinçlenmek gerekliliği ortadadır. Böylelikle medyanın yönlendirme gücü konusunda farkındalık oluşturularak, medya tarafından inşa edilen anlamlara dikkat çekilebilir ve üretilen şiddetin, cinsiyetçi, ırkçı bakış açısının sorgulanabilir hale gelmesi ${ }^{67}$ mümkün olabilir.

\section{Kaynakça}

Agtaş, Özge. "Nefret Söylemi, Dilsel Yaralama ve Siyasal Faillik”. Ayrımcılı̆̆ın Yüzleri.

Der., Ülkü Doğanay. Ankara: İHOP, (2018):63-78.

Akdeniz, Yaman. "İnternette Irkçılık”. Nefret Suçları ve Nefret Söylemi. Der., Özlem Dalkıran. İstanbul: Hrant Dink Vakfı Yayınları, 2010.

Bakıroğlu, Cemile Toksöz. "Sosyalleşme ve Kimlik İnşası Ekseninde Sosyal Paylaşım Ağları” XV. Akademik Bilişim Konferansında Sunulan Bildirileri, Akdeniz Üniversitesi, Antalya, 23-25 Ocak, 2013.

Bar-Tal, Daniel. "Formation and Change of Ethnic and National Sterotypes: An Integrative Model”. International Journal of Intercultural Relations. 21/4 (1997): 491-523.

Bell, Philip. "Content Analysis of Visual İmages”. The Handbook of Visual Analysis.

Ed., Theo Van Leeuwen and Carey Jewitt. London: Sage Publications, (2001): 10-34.

Binark, Mutlu. "Nefret Söyleminin İnternet Ortamında Dolaşıma Girmesi ve Türetilmesi”. Yeni Medyada Nefret Söylemi. Haz., Tuğrul Çomu. İstanbul: Kalkedon Yayınları, 2010.

Çeğin, Güney ve Mehmet Meder. "Sembolik Şiddet Arenası: Televizyon ve Medyatik Söylemin Özerkliği Sorunu”, Pamukkale Üniversitesi Eğitim Fakültesi Dergisi. 15/15, (2004): 102-107.

Çoban, Barış. "Medyanın Milliyetçi Söylemi: Medya, Öteki ve Şiddet”. Uluslararası Medya ve Siyaset Sempozyumunda Sunulan Bildiri, Ege Üniversitesi, İzmir, 1517 Kasım, 2007.

65 Burak Dogu, Zehra Ziraman and D. Emrah Ziraman. "Web Based Authorship in the Context of User Generated Content, An Analysis of a Turkish Web Site: Eksi Sozluk", 4th Global Conference on Cybercultures, Austria (March 2009), s.123.

66 Bar-Tal, "Formation and", s.517.

67 Uysal, "Medya ve Şiddet", s.126. 
Çoban Keneş, Hatice. "Yeni Irkçı Söylemlerin Eklemli Niteliği ve Medyanın İşlevi”. Ankara Üniversitesi, Sbf Dergisi, 69 (2014): 407-433.

Çomu, Tuğrul ve Mutlu Binark. "Yeni Medya Ortamlarında Nefret Söylemi”. Medya ve Nefret Söylemi. Ed., Mahmut Çınar. İstanbul: Hrant Dink Vakfı Yayınları, 2013.

Dogu, Burak, Zehra Ziraman ve D. Emrah Ziraman. "Web Based Authorship in the Context of User Generated Content, An Analysis of a Turkish Web Site: Eksi Sozluk." 4th Global Conference on Cybercultures, Austria (March 2009).

Doğanay, Ülkü. "Irkçılı̆̆ın İzini Satır Aralarında Sürmek: Popüler Kültür Ürünlerinde Irkçı Söylemlerin Yaygınlaşma Biçimleri”. Medya ve Nefret Söylemi. Ed., Mahmut Çınar. İstanbul: Hrant Dink Vakfı Yayınları, 2013.

Doğanay, Ülkü. “Ayrımcılık, Söylem ve Medya”. Ayrımcılı̆̆ın Yüzleri, Der., Ülkü Doğanay. Ankara: İHOP, (2018):16-39.

Ergün Takan, Duygu ve Müjgan Yağmur İçelli. “Dijital Mizah”. Medya ve Mizah. Der., Huriye Kuruoğlu ve Mikail Boz. Ankara: Nobel Akademik Yayıncılık, 2016.

Gidişoğlu, Sercan ve Kerem Rızvanoğlu. "İnternette Türk Milliyetçiliği: Türk Milliyetçisi Siteler ve Ağ Yapısı Üzerine Bir Analiz”. Nefret Suçları ve Nefret Söylemi. Der., Yasemin İnceoğlu. İstanbul: Ayrıntı Yayınları, 2012.

Gürel, Emet ve Mehmet Yakın. “Ekşi Sözlük: Postmodern Elektronik Kültür”. Selçuk Üniversitesi İletişim Fakültesi Akademik Dergisi. 4/4, (2007): 203-219.

Erdoğan, İrfan ve Korkmaz Alemdar. Öteki Kuram. Ankara: Erk Yayınları, 2005.

Hall, Stuart. “İdeolojinin Yeniden Keşfi: Medya Çalışmalarında Toplumsal Denetimin Kurulması ve Baskı Altında Tutulanın Geri Dönüşü”. Medya, İktidar, İdeoloji. Der. ve Çev., Mehmet Küçük. Ankara: Bilim ve Sanat Yayınları, 2005.

Hall, Stuart. "Kültür, Medya ve İdeolojik Etki”. Medya, İktidar, İdeoloji. Der. ve Çev., Mehmet Küçük. Ankara: Bilim ve Sanat Yayınları, 2005.

Haslam. Nick. "Dehumanization: An Integrative Review". Personality and Social Psychology Review. 10/3, (2006): 252-264.

İnceoğlu, Yasemin. “Önsöz”. Nefret Suçları ve Nefret Söylemi. Der., Yasemin İnceoğlu. İstanbul: Ayrıntı Yayınları, 2012.

Meşe, Gülgün. "Mizah ve Sosyal Psikoloji”. Medya ve Mizah. Huriye Kuruoğlu ve Mikail Boz. Ankara: Nobel Akademik Yayıncılık, 2016.

Ölçer, Hamit. "Pierre Bourdieu Sosyolojisinde Simgesel Şiddet Sorunsalı ve Biçimleri”. Nosyon: International Journal of Society and Culture Studies. 2 (2019): 34-49.

Özer, Ömer. "Medyada Şiddet Kullanımı: Şiddet Ekonomisi, Medyanın İdeolojik Şiddeti ve Yetiştirme Kuramı Açısından Bir Değerlendirme”. Marmara İletişim Dergisi. 27 (2017): 1-19.

Öztekin, Hülya. "Yeni Medyada Nefret Söylemi: Ekşi Sözlük Örneği”. Uluslararası Sosyal Araştırmalar Dergisi, 8/38 (2015): 925-36.

Palabıyıkoğlu, Refia. “Medya ve Şiddet”. AÜ. Kriz Dergisi. 5/2, (1997): 123-126.

Postman, Neil. Televizyon: Öldüren Eğlence. Çev., Osman Akınhay, İstanbul: Ayrıntı Yayınları, 2016. 
Sumbas, Ahu. "Batı Avrupa'da Yükselen Irkçılık Üzerine Bir Deneme". Alternatif Politika. 1/2 (2009): 260-281.

Torun, Ayla. "Öteki' ile 'Biz' İlişkisinde Yeni Medya, Sosyal ve Beşeri Bilimlere ve Küresel Yaklaşımlar: Kuram ve Uygulamalar” Uluslararası Sempozyumu. Varşova, Polonya, 16-18 Eylül 2015.

Trend, David. Medyada Şiddet Efsanesi- Eleştirel Bir Giriş. Çev., Gül Bostanc1, İstanbul: Yapı Kredi Yayınları, 2008.

Uysal, Meral. "Medya ve Şiddet". Bir Toplumsal Sorun Olarak Şiddet. Ankara: Eğitim Sen Yayınları, 2006.

Ünal, Serdar. "Irksal Temelli Ayrımcillğın Yeni Görünmez Yüzü: Kültürel Karşılaşmalar ve Mikro Saldırganlıklar". Journal of Social And Humanities Sciences Research. 5/28, (2018): 3288-3308.

Van Dijk, Teun. Racism and The Press. London, New York: Routledge, 1991.

Van Dijk, Teun. "Söylemin Yapıları ve İktidarın Yapıları". Medya, İktidar, İdeoloji. Der. ve çev., Mehmet Küçük. Ankara: Bilim ve Sanat Yayınları, 2005.

Van Dijk, Teun. "Söylem ve İktidar". Nefret Suçları ve Nefret Söylemi. Çev., Pınar Uygun. Der., Özlem Dalkıran. İstanbul: Hrant Dink Vakfı Yayınları, 2010.

Van Dijk, Teun. "Söylem ve İdeoloji: Çok Alanlı Bir Yaklaşım”. Söylem ve İdeoloji. Çev., Nurcan Ateş. Haz., Barış Çoban ve Zeynep Özarslan. İstanbul: Su Yayınevi, 2015.

Van Dijk, Teun. "Discourse and Denial of Racism". Discourse and Society. (1992): 87-118.

Van Dijk, Teun. "Racist Discourse". Routledge Encyclopedia of Race and Ethnic Studies. Ed., Ellis Cashmore. London: Routledge, 2004.

Van Dijk, Teun. "New(s) Racism: A Discourse Analytical Approach, 2000".

Yaylagül, Levent. Kitle İletişim Kuramları-Egemen ve Eleştirel Yaklaşımlar. Ankara: Dipnot Yayınları, 2017.

Yazıcı, Tülay. "Yeni Medyanın Nefret Dili: Suriyeli Mültecilerle İlgili Ekşi Sözlük Örneği". Global Media Journal TR Edition. 7/13 (2016): 136-115.

Zorlu, Yaşar. "Medyadaki Şiddet ve Etkileri". Humanities Sciences (NWSAHS). 11/1 (2016): 13-32. 
İNSAN\&İNSAN, Y11/Year 7, Say1/Issue 25, Yaz/Summer 2020, 65-84

DOI: https://doi.org/10.29224/insanveinsan.745785

\title{
Social Media and Violence: Chinese Perception in Ekşi Sözluk
}

\author{
ÇAĞLA PINAR TUNÇER
}

\begin{abstract}
The media, whose speed, influence and diffusion increase with technological developments, teaches, legitimizes, reproduces, normalizes the violence and the dominant values its "reality". The media uses symbolic violence expressed by hate speech. In this study, the discourses produced about China and Chinese after the pandemic in Eksi Sozluk, a popular platform of the new media, are examined. The entries were analyzed by content and critical discourse analysis, which themes were used about China and the Chinese, how they were marginalized and defined. As a result, hate speech about the Chinese, the negative stereotypes and prejudices were in circulation, conspiracy rhetoric was applied with the conspiracy theories and nationalist-religious references, dehumanization and intra-humanization were found. New media content, easily produced as its potential to turn into violence, has to be free from hate speech.
\end{abstract}

Keywords: New media, Violence, Hate speech, Pandemic, Chinese. 